\title{
Capitalismo dependente e as origens da "questão social" no Rio de Janeiro
}

\section{Dependent capitalism and the origins of the "social question" in Rio de Janeiro}

\author{
Rodrigo Castelo ${ }^{a}$ \\ (D) https://orcid.org/0000-0002-8927-1055 \\ Vinicius Ribeiro ${ }^{b}$ \\ (D) https://orcid.org/0000-0001-6609-6517 \\ Guilherme de Rocamora ${ }^{a}$ \\ (D) https://orcid.org/0000-0003-0627-5120
}

Resumo: 0 presente trabalho discute, a partir das particularidades do capitalismo dependente no Brasil, a gênese da "questão social" no estado do Rio de Janeiro. Nas duas primeiras partes, apresentamos algumas especificidades históricas da transição brasileira para o capitalismo em meados do século XIX e as mudanças do padrão de reprodução do capital agromineiro exportador para o industrial no estado fluminense. Na terceira, analisamos a luta das classes subalternas contra a superexploração do trabalho.

Palavras-chave: Capitalismo dependente. Questão social. Brasil. Rio de Janeiro.
Abstract: The present paper discusses, from the peculiarities of dependent capitalism in Brazil, the genesis of the "social question" in the state of Rio de Janeiro. In the first two parts, we present some historical specificities of the Brazilian transition to capitalism in the middle of the 19th century and the changes in the pattern of capital reproduction of exporting agricultural for the industrial sector in the state of Rio de Janeiro. In the third, we analyze the struggle of the subaltern classes against the overexploitation of labor.

Keywords: Dependent capitalism. Social question. Brazil. Rio de Janeiro. 


\section{Introdução}

\section{A} categoria "questão social" deve ser compreendida a partir das contradições existentes entre capital e trabalho no modo de produção capitalista e a formação da classe trabalhadora como sujeito histórico autônomo, ingressando na cena política a partir das suas lutas pela emancipação humana. Nesta perspectiva teórico-metodológica, o fundamento da "questão social" está expresso na lei geral da acumulação capitalista (Marx, [1867] 2017).

Uma análise concreta da "questão social", para além da apreensão universal da lei geral, deve envolver, todavia, as particularidades históricas que se busca estudar, isto é, a forma específica que adquiriu o desenvolvimento do capitalismo em determinada região (Netto, 2017). Com isso, podemos estabelecer as mediações para a teorização acerca do objeto e entender que a "questão social" em determinadas regiões possui aspectos particulares que não devem ser ignorados.

Dito isto, para analisarmos a gênese da "questão social" fluminense, objeto do presente texto, devemos compreender o processo de transição do Brasil para o capitalismo dependente, as particularidades do Rio de Janeiro nesse período e as heranças da escravidão e das lutas populares e quilombolas contra esse sistema de exploração e dominação. A formação social de transição apresenta elementos do velho e do novo em uma combinação bizarra. Numa transição curupira, caminhou-se para a frente com os pés voltados para trás. A seguir, buscamos expor esses elementos para, ao final, tratarmos da "questão social" no Rio de Janeiro no período de 1850 até 1922.

\section{A transição brasileira para o capitalismo dependente}

A colonização europeia redefiniu radicalmente os modos de produção e reprodução dos povos originários americanos. Civilizações e territórios foram destruídos em nome das formas antidiluvianas do capital, sob a 
bênção do Estado e da Igreja católica. Na Europa Ocidental Setentrional, foi um período de transição do feudalismo para o capitalismo. Aqui, nas Américas, a transição foi outra, embora intimamente relacionada ao que acontecia no continente europeu. Essa época ficou conhecida como a acumulação primitiva do capital.

O comunismo primitivo foi dizimado por uma política estatal de conquista do território e genocídio indígena que instaurou um sistema de dominação das populações locais e dos povos africanos. O objetivo foi implementar o escravismo como um sistema econômico de exploração do trabalho humano e dos recursos naturais nativos para exportação de mercadorias que atendessem aos interesses dos mercados externos. A violência como potência econômica e seus métodos brutais de expropriação - colonização, tributação regressiva, dívida pública e protecionismo - desembarcaram nas Américas para cumprir seus desígnios de impulsionar a acumulação capitalista na Europa.

O ingresso da América Latina no mercado mundial deu-se sob a égide da colonização, fundada no tripé da monocultura de exportação, do latifúndio e da força de trabalho escravizada indígena e negra. Em meados do século XIX, com a divisão internacional do trabalho comandada pelo Império Britânico, há uma mudança qualitativa da inserção latino-americana nos circuitos mundiais da acumulação de capitais, passando da colonização para o capitalismo dependente. Esse é um período de transição de modos de produção na América Latina.

Até então, a região era fornecedora de matérias-primas e alimentos para os países industriais centrais e a sua condição política era de colônia dos impérios europeus. Junto aos processos nacionais de independência no início dos anos 1800 , temos a transição dos modos de produção pré-capitalistas para o capitalismo dependente, tendo o trabalho livre como relação social de produção hegemônica, mas combinada com diversas outras formas tidas como arcaicas. Como diz Décio Freitas (1982, p. 131):

Medrou em toda parte uma pluralidade de modos de produção, nenhum dos quais em sua forma pura. As relações de produção parecem por muito 
tempo entremisturadas numa tal confusão que não se pode determinar qual a que exercia a dominância. No estado atual da investigação histórica, manda a prudência que se fale apenas em formação social de transição.

O Brasil participou dessa transição histórica de uma forma sui generis. E aqui é mais do que necessária a prudência indicada por Décio Freitas, tendo em vista que existe uma enorme controvérsia (ainda em aberto) sobre o caráter do modo de produção existente na América Latina antes da emergência do capitalismo dependente e quando teria começado e terminado essa transição histórica. ${ }^{1}$

Enquanto em diversos países da América Latina espanhola a independência foi realizada sob intensos combates militares entre frações das classes dominantes e com ativa participação popular, no nosso país a independência foi um acordo pelo alto entre os donos do poder, excluindo-se o protagonismo popular a partir do uso intensivo da coerção estatal. Além disso, o Brasil manteve intacta a sua estrutura econômica de latifúndios monocultores de exportação e de exploração da força de trabalho escrava, sendo o último país a banir a escravidão nas Américas. Isso deixou marcas profundas na nossa formação econômico-social, não somente do ponto de vista do racismo estrutural, mas também das desigualdades de classes e raças e da violência estatal contra os de baixo.

O fim da escravidão não pode ser reduzido ao ato formal de assinatura da Lei Áurea em 1888. Visto como uma concessão da monarquia, perde-se a dimensão das lutas geopolíticas entre o Império Britânico e o Brasil independente e das rebeliões quilombolas e populares. Na verdade, a extinção do escravismo no nosso país deve ser estudada como um longo processo de determinações externas e internas.

Podemos, contudo, indicar duas premissas aqui adotadas: (1) o modo de produção anterior ao capitalismo dependente não era feudal; (2) o capitalismo dependente emerge em torno de meados do século XIX, a partir de uma sucessão de fatores externos e internos. Sobre a extensa controvérsia sobre os modos de produção e as formações econômico-sociais na América Latina, indica-se a leitura de Luporini et al. (1973), Assadourian et al. (1974) e Lapa (1980). 
As pressões externas pelo seu fim começam nas primeiras décadas do século XIX, quando a Inglaterra aboliu o tráfico negreiro nas suas colônias, a despeito dos lucros mercantis extraordinários obtidos até então com a compra e a venda dos escravos africanos, manancial sanguinário da acumulação primitiva (Williams, [1944] 2012, cap. 2). Preocupadas com a formação de mercados consumidores para seus produtos manufaturados, as classes dominantes inglesas adotaram, sob o véu de uma súbita solidariedade humanista ungida de uma ética protestante, a política de combater o tráfico negreiro e a escravidão na América Latina. O Brasil, por se tratar do maior mercado importador de escravos africanos no mundo, é um dos alvos prioritários, com assinatura de tratados entre os dois países e de incursões militares dos ingleses no nosso país a partir do Bill Aberdeen (1845).

Em 1831, criou-se, sob pressão da diplomacia inglesa, uma lei que proibiu o tráfico negreiro. Essa lei, contudo, pertenceu ao rol das leis "para inglês ver". Os latifundiários brasileiros e traficantes portugueses de escravos pressionaram o Estado brasileiro a não adotar medidas efetivas para colocar em prática a lei promulgada. Somente em 1850, já com o Bill Aberdeen plenamente ativo, é que o Brasil começou a combater o tráfico negreiro e promulgou-se a lei Eusébio de Queirós. Depois disso, temos outras legislações - Ventre Livre em 1871 e Sexagenários em 1885 - para colocar uma pá de cal na escravidão. Em termos numéricos, o longo processo do fim da escravidão pode ser descrito da seguinte forma: em 1850, a população escrava correspondia a 31\% da população total; apenas dois anos depois, em 1852, esse percentual caiu para 15\%; em 1887, às vésperas da Abolição, o percentual era de somente 5\% (Moura, [1959] 1988, p. 67).

Nesse mesmo processo de extinção da escravidão, concorreu um fator essencial que muitas vezes passa despercebido por parte substantiva da bibliografia crítica sobre o tema: as lutas de resistências de escravos e escravas contra a exploração e a opressão. Clóvis Moura ([1959] 1988) destaca tanto as lutas populares e quilombolas — um fenômeno nacional de organização econômica, militar e cultural contra o escravismo, e não 
somente de fuga das senzalas - quanto a radicalização do movimento abolicionista, com a participação direta de mulheres e homens libertos da escravidão, com uma pauta de reivindicações que incluía a reforma agrária e o atendimento de necessidades sociais, como trabalho, educação, moradia etc. Em resumo, a pressão dos de baixo também criou abalos estruturais na ordem vigente; sem elas, o sistema já apodrecido poderia persistir por mais algum tempo.

Enquanto as velhas formas de produção não morreram e as novas não nasceram, vivenciamos o aparecimento de combinações de exploração de classes baseadas em métodos de coerção econômica e extraeconômica. $O$ trabalho escravo coexistiu com o trabalho livre em diversas regiões do país e setores econômicos. A coexistência entre modos de produção na formação econômico-social brasileira ia muito além do campo: estava presente no artesanato e nas manufaturas nascentes dos centros urbanos. Escravos e operários conviveram e vivenciaram - juntos, mas de maneira desigual - a opressão, a alienação e a exploração nos mesmos postos de trabalho e locais de moradia. Há um amálgama entre a escravidão e o trabalho livre (que anos depois se transformaria em assalariado) na formação do proletariado brasileiro, que tem suas raízes sociais nos indígenas, negros e imigrantes europeus (Vinhas, 1970, p. 128). E mais: escravos e trabalhadores livres lutaram juntos, no fazer-se da classe trabalhadora brasileira, contra o então decadente escravismo e o nascente capitalismo dependente. Conforme aponta Clóvis Moura (1988, p. 247):

Do ponto de vista em que nos colocamos em relação ao escravismo tardio o exemplo é significativo, pois demonstra como já existiam escravos trabalhando como operários e se associando a entidades de trabalhadores livres e, em contrapartida, a iniciativa de uma dessas entidades [Imperial Associação Tipográfica Fluminense] no sentido de modificar o status do seu associado, concedendo-lhe o título de cidadão.

Dessa configuração compósita de modos de produção e de formas de organização das classes subalternas, resulta que, apesar das diferenças 
existentes entre escravos e trabalhadores livres, a luta de classes no Brasil é intimamente imbricada com a questão racial. Essa particularidade histórica não pode ser negligenciada, sob pena de reproduzirmos uma perspectiva eurocêntrica sobre a "questão social". Florestan Fernandes ([1988] 2017, p. 85) explicita a essência teórica e as consequências políticas da particularidade histórica da "questão social" no Brasil ao escrever:

Se a classe tem de ser forçosamente o componente hegemônico, nem por isso a raça atua como um dinamismo coletivo secundário. A lógica política que resulta de tal solo histórico é complexa. [...] Classe e raça se fortalecem reciprocamente e combinam forças centrífugas à ordem existente, que só podem se recompor em uma unidade mais complexa, uma sociedade nova, por exemplo. Aí está o busílis da questão no plano político revolucionário.

Apesar de a transição histórica entre modos de produção na América Latina no século XIX possuir traços gerais, é importante ressaltar as particularidades de cada formação econômico-social, seja em uma análise em nível nacional e/ou regional. Desta forma, ressaltamos as especificidades do estado do Rio de Janeiro frente ao desenvolvimento desigual e combinado do modo de produção capitalista num país dependente como o Brasil. Os processos ocorridos no Rio ajudam a entender tais especificidades, pois foi no estado fluminense, junto com outras regiões e cidades (Porto Alegre, Recife, Salvador e São Paulo), que se gestaram os embriões do modo de produção capitalista e da classe trabalhadora no Brasil.

\section{Riqueza e poder no Rio de Janeiro: da economia agroexportadora à industrialização}

Em fins do século XVIII, a produção agrícola e mineira cumpria um itinerário peculiar para o capital mercantil metropolitano português: o escoamento para o exterior incluía invariavelmente as praças mercantis 
do litoral sul do país, em especial o Rio de Janeiro. O polo fluminense crescia em importância à medida que extrapolava aos poucos a função de porta de entrada e saída de produtos primários, razões ligadas fundamentalmente ao declínio da mineração e ao renascimento da agricultura.

Em 1808, no bojo da transferência da corte portuguesa para o Rio, o cenário colonial modificou-se profundamente com a abertura dos portos brasileiros ao comércio internacional e a revogação das disposições jurídicas que vedavam empreendimentos manufatureiros. Por conta dessas movimentações, o estado vivenciou de 1808 a 1822 "diversos 'surtos manufatureiros'” (Silva, 2007, p. 94), o que mostra, desde cedo, que a cidade e o estado não se limitaram a ser centros administrativo, comercial, financeiro e agroexportador; junto a essas atividades, houve o desenvolvimento das manufaturas.

A acumulação de capital comercial e fundiário no espaço urbano dinamizou um conjunto de atividades financeiras e econômicas em casas de negócios, manufaturas, pequenas indústrias, casas bancárias e serviços. O Rio de Janeiro assumiu gradualmente a posição de relevante centro consumidor e distribuidor de mercadorias. Em relação à pauta exportadora da economia fluminense nos primeiros anos do Império, os principais gêneros foram o açúcar, o fumo, o algodão, as peles e o café. Esta última mercadoria adquiriu importância decisiva para o novo ciclo de acumulação da economia brasileira. A sua curva ascendente se manifestou na passagem de cultura complementar ao algodão e ao açúcar no século XVIII a setor dominante da economia no XIX.

A economia cafeeira surgiu, portanto, conectada ao mercado externo. Desde o norte fluminense ao Vale do Paraíba, passando pela Baixada, as zonas cafeeiras do Rio de Janeiro possibilitaram o controle do mercado mundial do produto. Em 1843, o Brasil supria 40\% da oferta de café no mundo, percentual que ascenderia nas décadas seguintes. A economia cafeeira, além de expressar a cisão existente entre mercados externo e interno no contexto da transição brasileira para o capitalismo dependente, contribuiu significativamente para a mudança do eixo da 
acumulação baseado na mais-valia absoluta para a mais-valia relativa nos países centrais. A oferta de café com baixos custos de produção e sua integração aos bens de consumo necessários dos trabalhadores nas economias capitalistas centrais permitiu uma redução no valor real da força de trabalho naqueles países, uma vez que o café passou a atuar como estimulante aos trabalhadores em suas jornadas exaustivas, chegando até a substituir refeições (Luce, 2018).

De acordo com Marquese e Tomich (2009), o avanço do complexo cafeicultor do Vale do Paraíba corresponde à fase mais imediata de proibição do tráfico negreiro transatlântico - de 1830 em diante. Mesmo com a proibição, continuou o contrabando de escravos africanos, pois, além de atuarem como força produtiva, o comércio ilegal era uma das principais fontes de lucros mercantis na região. Ou seja, além das taxas brutais de exploração do trabalho escravo, a acumulação de excedentes na região continuou vigorosa com as transações ilegais do tráfico negreiro.

A região fluminense do Rio de Janeiro - à época dividida entre a província do Rio de Janeiro (1821-89) e o município neutro (1834-89) - cumpriu um papel central na dinâmica econômica do país, e não somente na produção agroexportadora de café, cana e outras mercadorias. $O$ excedente de capitais gerado pela produção agroexportadora foi investido no setor industrial, com destaque para a indústria têxtil, por meio da ação de comerciantes vinculados às oligarquias do café. Várias indústrias do setor têxtil foram criadas na cidade, uma vez ampliada a demanda por esse tipo de mercadoria, principalmente por parte do Exército brasileiro, devido à Guerra do Paraguai (Levy, 1994, p. 93-94). Assim, o desenvolvimento da indústria no Rio, que já era significativo nos setores de alimentos e bebidas, ganhou um salto de qualidade.

Além do setor têxtil, destaca-se também o metalúrgico, impulsionado principalmente pelas demandas do arsenal de Marinha de Guerra e posteriormente das encomendas militares derivadas da Guerra do Paraguai e pela construção da primeira malha ferroviária do país com capitais agrários e estatais, que começou em 1852 com a Estrada de Ferro Mauá 
(em Magé) e ganhou enorme impulso com a Estrada de Ferro Central do Brasil (Melo e Oliveira, 2016, p. 32-33). Podemos apontar também o setor químico-farmacêutico e as indústrias de "perfumaria, tintas, [...] calçados, vidros, curtume, chapéus, cigarros e papel”, além de "indústrias voltadas ao setor farmacêutico e de alimentação e bebidas, como as refinarias de açúcar" (Oliveira, 2008, p. 68-69).

Outro fator que impulsionou o processo de industrialização no Rio foi o boom da Bolsa de Valores, provocado pela ampliação da base monetária do país por meio de créditos disponíveis no mercado, títulos da dívida pública e emissões de moeda. Esse período, que teve início em 1888 e foi conhecido como Encilhamento, se estendeu pelo início da Primeira República. "Os três anos que se seguem são marcados por booms permanentes. $O$ aumento das transações bolsistas é de $84 \%$ em 1889 , de 98\% em 1890 e de 45\% em 1891" (Lobo, 1978, p. 459). No final do século XIX, o Rio sediava a única Bolsa de Valores do país, além de uma série de bancos estrangeiros, sendo a principal praça financeira nacional. Sobre a importância do Encilhamento para a industrialização da cidade e do estado, Robson da Silva (2007, p. 103) comenta:

Durante o encilhamento, a cafeicultura fluminense "desceu" de sua fase áurea, e o setor mercantil-financeiro local foi "empurrado" a diversificar seu portfólio de investimentos, o que determinou a aquisição de ações de diversos empreendimentos industriais, especialmente a partir da reativação do mercado acionário no ano de 1889.

Para além das fronteiras da capital, o norte fluminense foi um dos polos importantes da acumulação de capitais no estado. Com o declínio da extração aurífera no Brasil, a produção de açúcar voltou a ser, no final do século XVIII, uma importante fonte de renda para Portugal, e o norte fluminense se destacou como uma das novas fronteiras da monocultura açucareira. Todavia, a sua produção era essencialmente direcionada para o mercado consumidor em expansão da cidade do Rio de Janeiro. Desde meados do século XIX houve um significativo processo de concentração 
e centralização das pequenas unidades produtoras seguido da mecanização dos processos de trabalho. Passou-se dos pequenos engenhos para as usinas centrais, movidas por máquinas a vapor e, mais tarde, pela energia elétrica (Silva e Carvalho, 2004, p. 38-52). Tivemos, numa região afastada do grande centro, a combinação desigual entre latifúndio, trabalho escravo, monocultura produtiva voltada para o mercado interno e a intensificação dos processos manufatureiros e até mesmo fabris. Em 1866 foi fundada uma fábrica têxtil na cidade de Campos dos Goytacazes, e essa atividade industrial ganhou destaque regional e até mesmo nacional como o quarto município produtor do país, de acordo com o Censo Industrial de 1907 (Silva e Carvalho, 2004, p. 61).

Esse período do padrão agromineiro exportador trouxe um salto de industrialização para o Rio de Janeiro, ainda que subordinada à produção de bens primários para exportação. Esse salto se expressa no fato de que o "Rio de Janeiro (área do antigo Distrito Federal), até 1889, detinha 57\% do capital industrial brasileiro" (Hardman e Leonardi, 1982, p. 59). De fato, o último decênio do Império (1880-89) marcou o primeiro grande surto industrial no Brasil: "O número de estabelecimentos industriais, de pouco mais de 200 em 1881, ascende no último ano da monarquia para mais de 600" (Prado Jr., [1945] 1984, p. 259), sendo o Rio de Janeiro o polo dinamizador de desenvolvimento da indústria.

Desde a segunda metade do século XIX, a fronteira agrícola do café se deslocou para o oeste paulista, Minas Gerais e Espírito Santo, e o Rio de Janeiro experimentou uma queda na participação nacional como produtor cafeeiro. Na década de 1890, São Paulo suplantou o Rio como principal estado produtor de café do país. A partir de 1896, evidenciou-se um aumento das atividades industriais em São Paulo, principalmente devido à crise da produção de café no estado do Rio de Janeiro. Em 1907, o Rio de Janeiro era o líder absoluto da indústria de transformação, com uma participação de 37,8\% no produto industrial nacional (30,3\% na capital federal e 7,5\% no estado); São Paulo estava em segundo lugar, mas bem aquém do Rio, com 15,9\% do total (Gorender, 1981, p. 35). 
De todo modo, a locomotiva fluminense foi perdendo força a partir da década de 1910. O censo industrial realizado em 1919 evidenciou a predominância paulista: a porcentagem do valor industrial bruto do antigo Distrito Federal (DF) e do estado do Rio de Janeiro em relação ao total do Brasil era de 28,2\%; já a de São Paulo era de 31,5\% (Hardman e Leonardi, 1982, p. 59).

No conturbado período de transição entre o padrão de reprodução do capital agromineiro exportador para o industrial - que se abre na década de 1910 com as lutas sociais entre frações dos blocos de poder e destes com as forças populares e camadas médias, e se aprofunda com o tenentismo, a Coluna Prestes, o golpe de 1930, a guerra civil em 1932, o Levante da Aliança Nacional Libertadora (1935), o Estado Novo (1937) e os golpes integralistas (1938) —, o Rio de Janeiro ainda era central na acumulação capitalista e na supremacia burguesa. A predominância paulista no crescimento industrial não significou uma imediata perda de importância do Rio no padrão hegemônico de reprodução do capital no Brasil. Isto ficou evidente ao identificarmos que, apesar de o censo industrial de 1919 demonstrar a superioridade paulista, a diferença de participação no valor industrial bruto entre os dois estados era de apenas 3\%. Com o passar dos anos, a distância entre Rio de Janeiro e São Paulo, todavia, só fez aumentar em favor do estado paulista.

As mudanças efetuadas pelo governo Vargas, com a criação de empresas públicas de economia mista, reafirmaram o papel de destaque (mas já coadjuvante) do Rio de Janeiro: tanto o Instituto de Resseguros do Brasil (IRB) quanto a Companhia Siderúrgica Nacional (CSN) estavam sediadas no estado. Além disso, outras empresas se instalaram na região, com destaque para “a Cia. Vale do Rio Doce [...]; a Cia. Nacional de Álcalis, localizada no município de Arraial do Cabo; e a Fábrica Nacional de Motores (FNM), no município de Duque de Caxias (Oliveira, 2008, p. 93). O Rio de Janeiro, apesar de ultrapassado por São Paulo, permanecia relevante, inclusive do ponto de vista industrial.

Em suma, o gérmen do padrão industrial surgiu na base econômica do estado do Rio de Janeiro desde meados do século XIX, mas só se 
consolidou no início do século seguinte em São Paulo. Junto com o auge da economia agroexportadora no Rio de Janeiro, tivemos os primeiros passos do padrão de reprodução do capital industrial. E, posteriormente, com a estagnação e decadência do padrão de reprodução do capital agromineiro exportador no Rio de Janeiro, constatamos a consolidação desse mesmo padrão de reprodução do capital em São Paulo (com a mesma mercadoria exportada, o café) e o início da ascensão do padrão industrial.

A transição entre padrões de reprodução do capital se caracteriza pelo fato de que a nova relação dialética entre dominação-subordinação de um padrão a outro ainda está pouco definida, o que dificulta a análise desse período (Osorio, 2012). Em situações históricas específicas, observamos a combinação de mais de um padrão de reprodução do capital, sendo a tarefa da pesquisa identificar o padrão subordinado e o dominante. Identificar com clareza como se efetuou a passagem do padrão agromineiro exportador para o padrão industrial - que se expressa também na ascensão de São Paulo como polo dinamizador do padrão de reprodução do capital no Brasil — é uma tarefa árdua.

A última seção trata justamente da gênese da "questão social" no estado fluminense, buscando entender as particularidades histórico-regionais a partir da expansão desigual do modo de produção capitalista na formação econômico-social brasileira.

\section{A gênese da "questão social" no Rio de Janeiro}

O fazer-se da classe trabalhadora no Brasil é um longo processo que tem profundas raízes no período escravista. É um mito achar que a formação da classe trabalhadora começa nos centros urbanos do Sudeste com a militância dos operários fabris de origem estrangeira e que defendiam os ideais anarquistas. A classe trabalhadora brasileira é herdeira das lutas dos escravos e escravas, rurais e urbanos, que, durante cerca de meio século, compartilharam experiências com os trabalhadores livres. 
A coexistência entre trabalhadores livres e escravizados era comum na vida urbana do Rio de Janeiro. Os espaços de convivência compreendiam distintas esferas do ser social, tais como trabalho, moradia, alimentação, transporte e lazer. Os contatos diários entre escravos, ex-escravos libertos e trabalhadores livres se expressaram em um conjunto de experiências e modos de ser, comuns a uma massa de despossuídos e explorados. A formação da classe trabalhadora no Rio oitocentista surgiu sob o signo da exploração compartilhada de distintas classes subalternas, regidas sob diferentes relações sociais de produção, mas sob a dominância do tacão de ferro do capitalismo dependente. Diante dessa situação, trabalhadoras e trabalhadores livres e escravos erigem, gradualmente, uma agenda de lutas sociais na cena pública. Para isto, recolhem formas históricas de resistência, desde o aquilombamento até as greves operárias, passando pelo mutualismo, as rebeliões escravas e outras. Conforme destaca Marcelo Badaró Mattos (2008, p. 27-28),

Tais considerações assumem uma importância capital para o estudo dos processos de formação de classe, em que a consciência da nova classe constitui-se a partir da articulação de valores e tradições herdados da situação social anterior, ela também marcada pela luta de classes, embora não necessariamente compreendida em termos classistas por seus contemporâneos.

Na cidade do Rio oitocentista, constata-se uma mescla substantiva entre trabalhadores escravos e livres antes da proibição do tráfico negreiro. De acordo com o Censo de 1821, metade dos trabalhadores era de escravos, a outra de empregados livres. Em 1849, o Censo aponta 41\% da força de trabalho como escrava. Em 1872, eram somente 17,8\% (Mattos, 2008, p. 40-41).

Essa composição heterogênea e combinada da força de trabalho carioca também se expressa na divisão sociotécnica do trabalho. Múltiplas modalidades de exploração do trabalho são empregadas nos comércios formal e informal, nas oficinas e nas fábricas. Mattos (2008) registra 
dois casos bem específicos de exploração não assalariada: dos “engajados”, imigrantes que negociavam dívidas exorbitantes de viagem com os capitães dos navios que, por sua vez, repassavam-nos a brasileiros para explorar o trabalho; e dos africanos livres que, apreendidos após a proibição do tráfico em 1830, trabalhavam compulsoriamente para o Estado ou a concessionários por largos períodos.

Luiz Felipe de Alencastro (1988) observa que os escravos de ganho e de aluguel formavam parte considerável da rede de trabalho escravo da cidade. Nessa modalidade, o proprietário agia como possuidor de um ativo a extrair renda de aluguel. Essa forma de exploração do trabalho escravo dominou as ruas cariocas até a década de 1850. Os serviços de maior concentração de escravos de ganho eram o de comércio ambulante e o de transporte de carga - além de operários, marinheiros e quitandeiros de loja (Soares, 1988). Jacob Gorender (1978, p. 459-461) também registra a prostituição de ganho nas ruas cariocas como uma das formas de exploração da força de trabalho feminina escrava em favor dos seus proprietários. Por fim, as oficinas artesanais e manufaturas exploravam número expressivo de trabalhadores escravos que desempenhavam ofícios com diferenciados graus de especialização na divisão sociotécnica do trabalho.

Os primeiros operários das fábricas do Rio experimentavam jornadas extenuantes sob o despotismo fabril, assim como os escravos. A superexploração da força de trabalho era um ponto de convergência entre grupos do proletariado brasileiro em gestação. Os tipógrafos, por exemplo, passavam cerca de doze horas em oficinas insalubres. Tais condições impulsionaram a categoria a mobilizar uma greve em 1858 por reajuste de salários numa conjuntura de fome e miséria. A Imperial Associação Tipográfica, de caráter mutualista, exerceu papel ativo de organização da categoria em torno dos direitos do trabalho.

Um ano antes da greve dos tipógrafos, temos um evento significativo do período inicial da formação da classe trabalhadora fluminense lastreada pela escravidão: a paralisação de trabalhadores escravizados 
no Estabelecimento de Fundição e Estaleiros da Ponta D’areia, maior empresa privada do setor na época (e integrante do império Mauá), com cerca de seiscentos operários, sendo 150 escravos. Em 26 de novembro de 1857, os escravos se recusaram a trabalhar enquanto três companheiros foram mantidos presos por desobediência. Na ocasião, 32 trabalhadores escravos foram presos. E, antes disso, Mattos (2004, p. 18-19) registra movimentos de rebelião escrava numa loja de caldeireiro na rua da Alfândega em 1833 e numa fábrica de velas e sabão na Gamboa em 1854. Diferentemente das greves dos tipógrafos, tais movimentos de luta escrava foram duramente reprimidos pelos gendarmes cariocas, sempre de prontidão para reestabelecer a "ordem pública".

Da metade do século XIX em diante foram representativos os movimentos grevistas em defesa de melhores condições de trabalho, com destaque para a luta dos caixeiros contra a abertura do comércio aos domingos (1866), a greve dos cocheiros da Botanical Garden pela reintegração de trabalhadores demitidos (1873) e a greve de operários da construção pelo pagamento de salários atrasados (1888), dentre tantas outras.

Na Primeira República (1889-1930), o Rio de Janeiro experimentou profundas transformações econômicas, políticas, sociais e culturais. Caixa de ressonância nacional pelo longo histórico de lócus do poder político-administrativo, a capital federal da República encarnou tensões e contradições vivas. A escravidão selou parcela significativa dos novos trabalhadores negros livres que, no Rio de Janeiro pós-Abolição, engrossou camadas sociais de desempregados e subempregados.

Nesse período, o trabalho urbano e o conflito social tinham dinâmicas próprias da expansão capitalista. Até os anos iniciais da década de 1920, a cidade do Rio de Janeiro reunia o maior contingente operário do país (Fausto, 2016, p. 33). No campo das lutas sociais, novas formas de ação e organização proletárias operaram transformações substanciais na "questão social" no estado, com rebatimentos no país inteiro. As reivindicações operárias tocaram os temas diretos da economia - de 
salários e melhores condições de trabalho - e da política, esta última no sentido da democratização da República oligárquica. A luta por direitos básicos de organização, manifestação, greve, descanso semanal, férias e aposentadoria encarnou o processo de construção do projeto classista dos trabalhadores.

Foi nesse contexto que as ideias anarquistas circularam com importante incidência no movimento operário. Pelos portos do Rio de Janeiro e de Santos - centros de afluência de mercadorias, pessoas e ideias passavam folhetos, livros e jornais anarquistas vindos da Europa. Nas ações operárias, os anarquistas denunciavam o conteúdo de classe do Estado e o caráter fraudulento do sistema político-eleitoral. Tais questões compareceram na participação anarquista das lutas do operariado da década de 1910: redução da jornada de trabalho, campanha contra a carestia nos biênios de 1912-13 e 1917-18 e deflagração de greves.

Nesse período, mesmo com a hegemonia dos anarquistas, tínhamos orientações políticas diversificadas nas organizações de trabalhadores. Em grupos, ligas, sindicatos, cooperativas e associações mutualistas conviviam anarquistas, sindicalistas revolucionários e socialistas. O fim da década de 1910 é especialmente agitado pela exponenciação de crises econômicas em razão da Primeira Guerra Mundial, pelas atividades numerosas de política operária por meio de uniões, ligas, federações e sindicatos e pela Revolução Russa (1917), que vai impactar o movimento operário brasileiro, com a mudança da hegemonia anarquista para os comunistas.

Nos principais periódicos operários do ano de 1917, os temas presentes são: o processo revolucionário russo, a greve geral operária em São Paulo, denúncias da política econômica subserviente ao capital estrangeiro, as prisões ilegais em profusão, a invasão de casas de pessoas pobres pela polícia, a campanha contra a participação do Brasil na guerra e outras questões candentes da conjuntura nacional e internacional, sempre com destaque para a política das classes dominantes nos estados da federação, a questão social, o operariado, as lutas sociais e a revolução (Sodré, 1999). 
A revolução proletária, presente na pauta política dos trabalhadores desde as agitações anarquistas, com destaque para a greve geral de 1917 em São Paulo e do levante armado em 1918 no Rio de Janeiro, ganhou um novo impulso com a criação do Partido Comunista Brasileiro (PCB) em março de 1922 na cidade de Niterói (RJ). Antigos dirigentes anarquistas, como Astrogildo Pereira e Octávio Brandão, passaram a militar na organização comunista e a defender novos métodos de ação e organização do proletariado rumo à concretização da revolução brasileira. O PCB não foi o primeiro grupamento partidário da classe trabalhadora, mas sim o que resistiu no tempo e, mais tarde, se tornou a primeira organização nacional política de massa do proletariado no Brasil, marcando uma nova época da "questão social" no Rio de Janeiro e no país como um todo.

\section{Referências}

ALENCASTRO, Luiz Felipe. Proletários e escravos: imigrantes portugueses e cativos africanos no Rio de Janeiro, 1850-1872. Novos Estudos, São Paulo, n. 21, p. 30-56, jul. 1988.

ASSADOURIAN, Carlos et al. Modos de producción en America Latina. Córdoba: Pasado y Presente, 1973.

FAUSTO, Boris. Trabalho urbano e conflito social: 1890-1920. 2. ed. São Paulo: Companhia das Letras, 2016.

FERNANDES, Florestan. Luta de raças e de classes. In: Significado do protesto negro. São Paulo: Expressão Popular; Fundação Perseu Abramo, [1988] 2017. p. 77-87.

FREITAS, Décio. O escravismo brasileiro. 2. ed. Porto Alegre: Mercado Aberto, 1982.

GORENDER, Jacob. O escravismo colonial. São Paulo: Ática, 1978.

A burguesia brasileira. São Paulo: Brasiliense, 1981.

HARDMAN, Foot; LEONARDI, Victor. História da indústria e do trabalho no Brasil: das origens aos anos 20. São Paulo: Editora Ática, 1982.

LAPA, José Roberto do Amaral (org.). Modos de produção e realidade brasileira. Petrópolis: Vozes, 1980.

LEVY, Maria Bárbara. A indústria do Rio de Janeiro através das suas sociedades anônimas: esboços de história empresarial. Rio de Janeiro: Editora da UFRJ, 1994. 
LOBO, Eulália. História do Rio de Janeiro (do capital comercial ao capital industrial e financeiro). Rio de Janeiro, IBMEC, 1978. v. 2.

LUCE, Mathias Seibel. Teoria marxista da dependência: problemas e categorias - uma visão histórica. São Paulo: Expressão Popular, 2018.

LUPORINI, Cesare et al. El concepto de "formación económico-social". Córdoba: Pasado y Presente, 1973.

MARQUESE, Rafael; TOMICH, Dale. O Vale do Paraíba escravista e a formação do mercado mundial do café no século XIX. In: GRINBERG, Keila; SALLES, Ricardo (orgs.). O Brasil Imperial: v. II: 1831-1870. Rio de Janeiro: Civilização Brasileira, 2009. p. 340-383.

MARX, Karl. O capital: crítica da economia política. Livro 1: O processo de produção do capital. São Paulo: Boitempo, [1867] 2017.

MATTOS, Marcelo Badaró. Greves e repressão policial aos sindicatos no processo de formação da classe trabalhadora carioca (1850-1910). In: (coord.). Trabalhadores em greve, polícia em guarda: greves e repressão policial na formação da classe trabalhadora carioca. Rio de Janeiro: Bom Texto; Faperj, 2004. p. 9-57.

Escravizados e livres: experiências comuns na formação da classe trabalhadora carioca. Rio de Janeiro: Bom Texto, 2008.

MELO, Hildete Pereira de; OLIVEIRA, Adilson de. Café e petróleo: um paralelo histórico. Cadernos do Desenvolvimento Fluminense, Rio de Janeiro, n. 10, 2016, p. 29-39.

MOURA, Clóvis. Rebeliões da senzala: quilombos, insurreições, guerrilhas. 4. ed. Porto Alegre: Mercado Aberto, [1959] 1988.

Sociologia do negro brasileiro. São Paulo: Ática, 1988.

NETTO, José Paulo. Uma face contemporânea da barbárie. In: BRAZ, Marcelo (org.). José Paulo Netto: ensaios de um marxista sem repouso. São Paulo: Cortez, 2017. p. 56-88.

OLIVEIRA, Floriano. Reestruturação produtiva, território e poder no Rio de Janeiro. Rio de Janeiro: Garamond, 2008.

OSORIO, Jaime. Padrão de reprodução do capital: uma proposta teórica. In: FERREIRA, Carla; OSORIO, Jaime; LUCE, Mathias (org.). Padrão de reprodução do capital: contribuições da teoria marxista da dependência. São Paulo: Boitempo, 2012. p. 37-86.

PRADO JR., Caio. História econômica do Brasil. 30. ed. São Paulo: Brasiliense, [1945] 1984. SILVA, Robson Dias da. Território e desenvolvimento: as raízes da centralidade do Rio de Janeiro na economia nacional. Estudos Históricos, Rio de Janeiro, n. 40, jul./dez. 2007, p. 91-113. 
SILVA, Roberto Cezar Rosendo Saraiva; CARVALHO, Ailton Mota de. Formação econômica da região norte fluminense. In: PESSANHA, Roberto Moraes; NETO, Romeu e Silva (org.). Economia e desenvolvimento no norte fluminense: da cana-de-açúcar aos royalties do petróleo. Campos dos Goytacazes: WTC, 2004. p. 27-75.

SOARES, Luiz Carlos. Os escravos de ganho no Rio de Janeiro do século XIX. Revista Brasileira de História, São Paulo, v. 8, n. 16. p. 107-142, 1988.

SODRÉ, Nelson Werneck. História da imprensa no Brasil. 4. ed. Rio de Janeiro: Mauad, 1999. VINHAS, Moisés. Estudos sobre o proletariado brasileiro. Rio de Janeiro: Civilização Brasileira, 1970.

WILLIAMS, Eric. Capitalismo \& escravidão. São Paulo: Companhia das Letras, [1944] 2012.

\section{Sobre os autores}

Rodrigo CAstelo - Professor da Universidade Federal do Estado do Rio de Janeiro, Escola de Serviço Social, Departamento de Serviço Social.

E-mail: rodrigo.castelo@gmail.com

VInicius Ribeiro - Assistente Social, Mestre em Serviço Social da Universidade Federal do Rio de Janeiro.

E-mail: ribeiro.vinicius@gmail.com

GuILHERME DE ROCAMORA - Graduando e bolsista de Iniciação Científica. E-mail: rocamora.g@gmail.com 